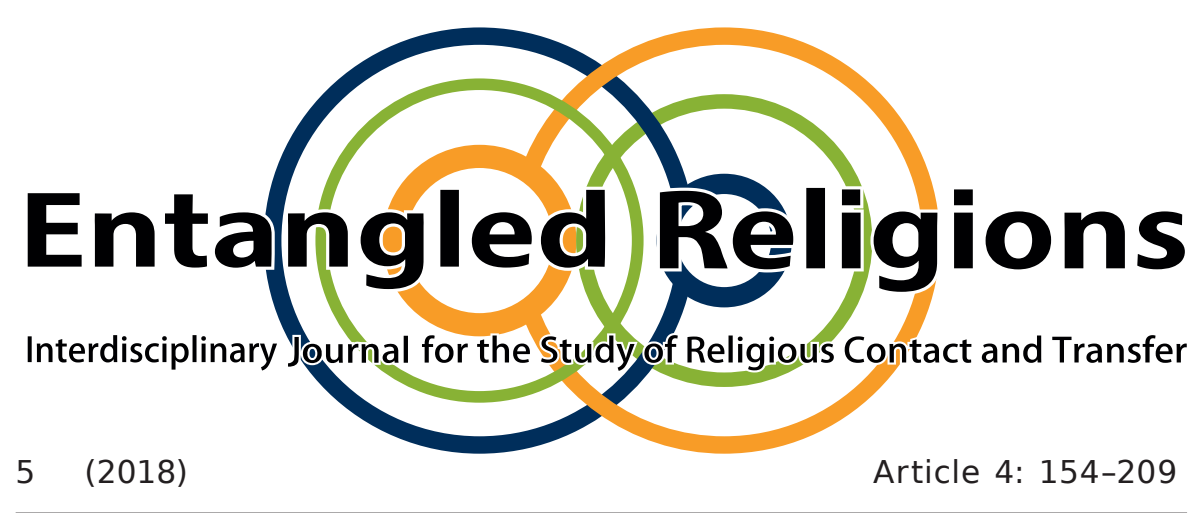

Evangelicals and the Encounter with Islam: Changing Christian Identity in Multi-Faith Britain

GREG SMITH

William Temple Foundation, England

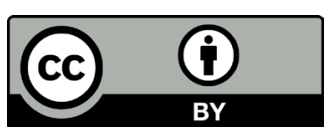

This contribution to Entangled Religions is published under the Creative Commons Attribution 4.0 International Public License (CC BY 4.0 International). The license can be accessed at https://creativecommons.org/licenses/by/4.0/legalcode.

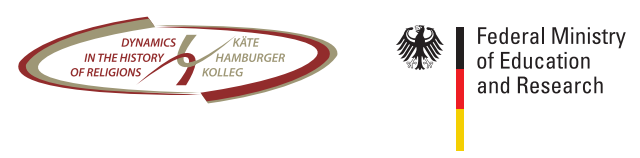




\title{
Evangelicals and the Encounter with Islam: Changing Christian Identity in Multi-Faith Britain
}

\author{
GREG SMITH \\ William Temple Foundation
}

\begin{abstract}
Over the last fifty years, British society has changed from a Christendom model, where the default religious identity was Church of England, to a religiously diverse society, where religious identity is a significant marker for minorities in the population. Among Christians, strong religious belief and belonging is most likely to be expressed by those who identify as evangelical. In many parts of the world, and especially in the USA, evangelical discourse on the subject of non-Christian faiths, especially Islam, suggests profound antipathy to 'other' beliefs and sometimes hostility to their adherents. In contrast, evidence presented in this paper from a recent Evangelical Alliance panel survey suggests a range of nuanced views in the community of evangelical Christians in the UK. Although over $80 \%$ affirmed that Jesus is the only way of salvation, and $84 \%$ thought Christianity is the only path to God, more extended comments show that a wide range of views exist, from the paranoid or exclusive to a view that is tolerant and broadly inclusive. The paper will examine the associations between these views and various demographic and theological factors and seek to explain the data in terms of the patterns of contemporary everyday inter-faith encounters, with specific emphasis on the Abrahamic faiths, especially Islam. The situation is discussed in a framework of dynamics and stability, where religious contact between faith communities has both crystallized beliefs and identities and opened up new possibilities for alliances against the secular world.
\end{abstract}

KEY WORDS evangelicals; inter-faith; Islam; Christianity; Britain 


\section{Introduction: Continuity and Change in Christian Views of Other Faiths ${ }^{1}$}

In the contemporary era of globalisation and electronic communication, religious diversity in cities and the negotiation of relationships and interactions between individual members of different faith communities is an everyday experience. Religious and other identities contesting minority rights are a salient feature of politics, sometimes leading to serious conflicts. In the early years of the twenty-first century, the relationship between societies and communities based on the residual Christendom of Europe and North America and those rooted in the world of Islam has been one of the most pressing issues of the age. Both nation states and non-state actors have been engaged in armed conflicts, which have been described variously as "the war on terror", "jihad", and "the war on Islam", in which millions (the vast majority being Muslims) have died or suffered.

It could be argued that a contrast of two main approaches to the relationship between Christianity and Islam goes back at least to the age of the Crusades in the twelfth century CE, when one section of the church was engaged in armed conflict with the Muslim world while the Franciscans sought peaceful relations through which they might convince Muslims of the truth of the Christian gospel (Cunningham 2004, 2006). The aim of this paper is to test how far the 'Crusader' view, which seems dominant in the USA, is adopted among the evangelical Christian community in the United Kingdom.

Arguably, evangelicals on both sides of the Atlantic are part of a global movement or community within Christianity. The relationships,

1 The survey research on which this paper draws was carried out and funded through the Evangelical Alliance, who have made the data available to researchers through the UK Data Archive, and to the author as a former member of staff. Opinions expressed in the paper are the views of the author alone. 
communication channels, and sense of common identity between British evangelicals and white conservative evangelicals in the USA might lead us to expect extreme hostility to Islam flourishing in some Christian circles in the UK.

Within Christianity, evangelicalism is frequently assumed to be especially problematic in the arena of inter-religious relations, and not without reason, for in many parts of the world, and especially in the USA, evangelical discourse on the subject of non-Christian faiths, and on Islam in particular, suggests profound antipathy to 'other' beliefs and sometimes hostility to their adherents. This resonates with the populist turn in politics which brought Donald Trump to the White House, with the support of $81 \%$ of white evangelicals who voted in the presidential election of November 2016 (Smith and Martínez 2016).

Within the rhetoric of Trump's campaign, one can detect a perception of all Muslims as fundamentalist extremists and potential terrorists, and an implicit paranoia that Islam is in a conspiracy to take over the world. If the assessment by Gidron and Bonikowski (2013) quoted below is to be believed, Richard Hofstadter's The Paranoid Style in American Politics (1964) appears strangely prescient, if not indeed prophetic:

The central feature of the paranoid style is the concern about an allencompassing conspiracy that threatens to take control of America and change its most foundational values. For Hofstadter, the prominence and persistence of the paranoid style in American politics is at least partially 'a product of the rootlessness and heterogeneity of American life and, above all, its peculiar search for secure identity'. (9)

Among white US evangelicals, the accusation that President Obama was a Muslim is commonplace, despite his professed Christian faith and 
church membership. Survey research suggest that Republicans, white evangelicals, and those with less education express most reservations about Muslims (Pew Foundation 2017).

A leading conservative evangelical, Franklin Graham (son of the worldfamous Billy Graham), is widely reported over many years as saying things such as, "We're not attacking Islam but Islam has attacked us. The God of Islam is not the same God. He's not the son of God of the Christian or Judeo-Christian faith. It's a different God, and I believe it is a very evil and wicked religion," and, "I don't believe this [Islam] is this wonderful, peaceful religion" (CNN report 2003; Goodstein 2003). More recently (and more clearly attributable), in a post to his Facebook page in July 2015, Graham proclaimed that

all Muslims should be barred from immigrating to America and treated like the Japanese and Germans during World War II. Muslims who come to America have the "potential to be radicalized" and participate in "killing to honor their religion and Muhammad". (Graham 2015)

The social media comments from readers of this post (which gained over 166,000 "likes") were overwhelmingly supportive and, in many cases, much more extreme in their language and level of hostility to Muslims. Numerous other posts expressing hostility to Islam and Muslims that goes far beyond fair comment about theological disagreements between Christianity and Islam can be found on the page over recent years.

Although Graham can be seen as typical of the evangelical church leadership in the USA, there is a minority view that is more eirenic. Hartley (2016) describes how some religious exclusivists may be taking inclusive action by adopting a more conciliatory tone and seeking to build neighbourly relationships with Muslims, while remaining firm in their 
theological conviction that salvation is uniquely to be found in Jesus Christ. Such Christians are actively networking through the Neighborly Faith Website (2018).

Cimino's article "No God in Common" (2005) is one of the few academic analyses of the ways in which American evangelicals discuss Islam polemically and in the light of prophesy and their interpretation of eschatology, which centres on the pre-millennial rapture of the saints and apocalyptic warfare-in which Islam is associated with the 'beast' and Satan. Kidd's major study (2009) demonstrates the stability of major themes in the relationship between the two faiths throughout the history of the American church. Kidd highlights the tension and historical shift between postmillennialist views, which have focused on the evangelism and conversion of Muslims, and pre-millennial views, which major on eschatology and see Islam as one of the enemies to be destroyed at the return of Christ. He also draws out the significance evangelicals place in the establishment of the State of Israel, their espousal of Christian Zionism, and their widespread and uncritical support of the military actions of the Israeli government. One significant difference between the USA and the UK is that in the former, premillennialism appears to be the dominant and highly salient understanding of eschatology among evangelicals, while in the UK, though not unknown in some evangelical circles, it has not captured the imagination of the majority of evangelicals and is rejected by many scholars, pastors, and teachers. Nor has there been a widespread acceptance of Zionism; indeed, many British Christians have more sympathy with and pray and work for peace and justice for the Palestinian people under occupation, e.g. through such organisations as The Amos Trust and Embrace the Middle East. 


\title{
Evangelicalism in Britain
}

In attempting to define the distinctive characteristics of the global evangelical movement, but with particular emphasis on the British context, Bebbington says:

\begin{abstract}
There are the four qualities that have been the special marks of evangelical religion: conversionism, the belief that lives need to be changed; activism, the expression of the gospel in effort; biblicism, a particular regard for the Bible; and what may be called crucicentrism, a stress on the sacrifice of Christ on the cross. Together they form the quadrilateral of priorities that is the basis of evangelicalism (1989, 2-3).
\end{abstract}

Since 1846, the Evangelical Alliance in the UK and the World Evangelical Alliance have sought to bring together in unity and fellowship those from a wide range of Protestant denominations, from Anglican to charismatic and Pentecostal, who share these emphases around a common doctrinal basis that aligns with these characteristics. On both sides of the Atlantic, among evangelicals there is a spectrum of beliefs, ecclesiology, and practices, ranging from fundamentalist to open and progressive (Bauder et. al 2011), while according to Baillie, in the UK “the Evangelical Alliance identify a spectrum of denominational and theological groupings within the movement which they call the 'twelve tribes of evangelicalism'" $(2002,6)$.

There are few published studies of evangelicals in the UK, but research reported in Smith (2015), especially in the chapter by Holmes, reflects on the changing and contested theology and identity of British evangelicals. It suggests a trend is emerging whereby younger evangelicals are becoming more reluctant to identify using the 'evangelical label', possibly for fear of association with the extreme conservative views of American evangelicals 
as portrayed in secular media and popular discourse. Strhan's perceptive ethnographic study of one evangelical church in London (2015) explores the identity and lifestyle of a counter-cultural minority group in a diverse and secular city. In such a setting, one might expect Christians to define themselves over against people of other faiths whom they encounter daily, yet secular humanism appears to be the main foe. However, as an ethnographic case study of one middle- to upper-class Anglican congregation in the Reformed Conservative evangelical 'tribe', Strhan's work cannot hope to capture the variety of expressions of evangelical Christianity. Her subsequent article (2014) majors on the contested area of sexuality and evangelical discomfort with LGBT rights. The emphasis on this aspect of contemporary cultural identity and legislative issues around it in recent years has been taken by some as a boundary-defining marker for evangelicalism, with the assumption that one cannot support equal same sex marriage and remain within the evangelical fold. Yet the existence and growth of networks such as Accepting Evangelicals suggest that this has become a contested issue.

Returning to the main theme of evangelical approaches to other faiths, it is significant that the classic boundary markers of evangelicalism have invariably been stated with reference to other Christian theologies, specifically Roman Catholic and 'liberal' Christianity. The statements of faith of the Evangelical Alliance (n.d.) and similar organisations seem to contain no explicit reference to religious diversity or the "theology of religions". Yet their own surveys suggest that the uniqueness of Christ is held by the vast majority $-84 \%$ thought "Christianity is the only path to God" (compared to 28\% of 1498 Anglican clergy surveyed by YouGov in 2014). In a post-Christendom context of religious diversity, where tolerance and freedom of religion are deeply embedded and even promoted in legislation and popular culture, this alone tends to mark out evangelicals 
as a countercultural minority. Yet as we shall seek to show, the evidence suggests some level of long-term stability in this area, but also a dynamic process of negotiation and nuance in addressing contemporary social realities.

\section{Evangelical Missiology}

The historical study of the missionary movement, which was associated with the expansion of the British Empire in the century or so after the American Revolution, uncovers some long-term continuities (Neill 1964; Hewitt 1971; Murray 1971; Porter 2000, 2004). Despite the loss of American colonies, Anglo-Saxon religious culture and theology retained many common features. The evangelical revivals of the eighteenth century inspired early British missionaries such as William Carey, Henry Martyn, and Alexander Duff to travel to the 'Orient' with a view to preaching the gospel among Muslims and Hindus (Atherstone 2018; Gladwin 2018). For the most part, their eschatological understandings were of the post-millennial school, with faith that the nations and other religions of the world would turn to Christ in large numbers, leading to advances in the 'civilization' of these societies and of the Kingdom of God, with the ultimate effect of ushering in the return of Christ (Gladwin 2018, 164). The accounts of some of the pioneers suggest they were relatively empathetic to the cultures and people of the East, and several of them became notable scholars and interpreters of unfamiliar languages and religions. However, the growing alliance between the missionary movement and British imperial power, especially after the 1857 Indian War of Independence, or 'mutiny' and its bloody suppression, tended to produce greater levels of hostility and suspicion, and, in many respects, explicit racism and Islamophobia (Atherstone 2018, 135). In any 
case, the evident lack of success in the evangelical project to produce large-scale conversions, especially of Muslim communities, resulted in widespread disappointment and a perception of Islam as particularly resistant to the Christian gospel, which continues to this day (Atherstone 2018, 135ff).

The literature on contemporary British evangelical relations with and approaches to other faith communities is relatively thin, and for the most part one can only rely on the study of published texts from Christian publishers. Compared with what we have described for the USA, among British evangelicals there has been a much wider spread of views and a generally more tolerant attitude, as evidenced in the collection of essays edited by Bell and Chapman (2011). From personal observation and engagement with urban churches, I believe that one is more likely to hear views hostile to Islam and suspicious of Muslims from African, South Asian, and Middle Eastern Christians in diaspora in the UK than from the mainstream white British Christian community, which may be founded on the basis of tense inter-communal relationships in the home countries. And within the UK, the further one goes from London and other multicultural neighbourhoods, the more likely one is-at least in my experience-to encounter hostility to and incomprehension of other faiths. McCallum's doctoral thesis (2011a) and subsequent publications (2011b, 2012, 2016) present the only extensive treatment of the topic, and benefits from his insider knowledge as an evangelical engaged in cross-cultural mission and interfaith work. 


\section{Religion, Politics, and Inter-Faith in Britain}

As a final section before moving on to the presentation of data, it is worthwhile saying something about the emergence of Britain's multi-faith society since 1945 and the politics and policies around multiculturalism and religious diversity down to the 'moment' of the Brexit referendum of 2016. With the postwar retreat from Empire and specific labour shortages in the British economy, a variety of push and pull factors led to significant waves of migration for over a quarter of a century from 1948. While immigrants from the Caribbean were predominantly Christian, and often far more zealous in their faith than the average English person, those originating in South Asia had strong religious identities as Muslims, Hindus, and Sikhs, with a minority who were Christians. Furthermore, they used languages and cultural practices which bore little relation to those of Christian England (or even Europe), yet during that period, identity and discrimination discourses measured almost everything in terms of skin colour; white $v$ black (or 'coloured', as it was termed in the vocabulary of the 1960s) with occasional footnotes about brown and yellow skinned groups. Through the 1980s and 1990s, the turn in social science towards cultural studies led on to the rise of identity-based community development and politics. As long ago as the early 1980s, I was writing about identity formation in terms of ethnic groups and boundaries (following Barth [1969] 1998) and identified religion as a possible boundary marker which could be mobilised alongside, or as an alternative to, race, ethnicity, nationality, and (heritage) language, also suggesting practices of bilingualism involving code switching and code mixing as an indicator of fluidity and hybridity of social identities (Smith 1983). All of this was, of course, grounded in a social constructionist approach which refused to reify categories or essentialise 
group belonging or characteristics based on stereotypes, though not denying that differences had some measure of empirical reality.

The Iranian Revolution of 1979 was one of the key world events which brought religion back into salience in public discourse across the globe, and in particular triggered a new confidence in asserting distinctive but global Islamic identities. The Rushdie affair of 1989, when death threats were made against the author of The Satanic Verses, was a turning point for religious identities in Britain, with Muslims mobilising in street demonstrations and book burnings in cities such as Bradford to express their outrage at what they believed to be an offense against Islam. At the same time, the disintegration of the Soviet block, in the context of the Soviet failure to subdue Afghanistan, followed by the wars in the Balkans, introduced a religious dimension to global politics. Articles such as Barber's “Jihad v McWorld” (1992), Huntington's “Clash of Civilisations" (1993), and a series of books by Bernard Lewis (1994, 2002, 2004) were significant in promoting the notion of a world divided by religion between the 'Christian' West/North and the Islamic world.

Meanwhile, from about 1990 onwards, the British government had sought to accommodate or possibly co-opt faith communities and their leadership into the policy agenda around issues such as inner-city regeneration and community development. The early stages of government policy through the Inner-city Religious Council are covered by Taylor (2003); regeneration and community involvement are described by Smith $(2002,2004)$ as religion and the rise of social capitalism. In 1997 in Britain, the Runnymede Trust report coined the term "Islamophobia" to describe the commonplace experience of racism against Muslims as they refined the description in their 2017 anniversary report.

2001 was a highly significant year; a series of 'riots' in towns in the North of England were interpreted in the report to government by Cantle 
(2001) as the result of high levels of residential segregation and deprivation and the 'parallel lives' of white British and Pakistani Muslim communities. Such local events were eclipsed by the attacks on New York in September and the subsequent wars in Afghanistan and Iraq. The military interventions were generally and often vigorously opposed by British Muslims and huge numbers of other British people. Following these events, UK government policy put the emphasis on programmes of community cohesion and securitisation. Anti-extremism policies, such as the Prevent Programme, sought to define parameters for an acceptable form of British Islam (Birt 2006). The official support of the Interfaith Network as described by AbdulAzim Ahmed (2015) privileged the liberal, open, and more pluralist actors in all the major world religions. Evangelical churches by and large were not greatly involved in the politics and programmes promoted by government, with some exceptions on the part of those located in religiously diverse cities. When new equalities legislation was enacted in 2010 and the teaching of 'British values' in schools was made compulsory, there was a degree of suspicion in some quarters (both Muslim and Christian) that laws designed as protection against hate crime and hate speech might be used to restrict religious freedom and historic privileges.

Various factors in recent years, including 'the War on Terror', the economic crash of 2008, the free movement of labour within an expanded EU, and the refugee crisis resulting from the conflict in Syria and Iraq, has tended to harden views on immigration and to embolden racist and anti-Islamic voices. UK government policy has seen a move away from acceptance of multiculturalism towards programmes of integration, with emphasis on English language learning, focused on Muslim women, as advocated in the Casey review (2016). Such women were widely perceived as uneducated, economically inactive, and particularly segregated in their 
own ethnic and linguistic communities, in an unfortunate reminder of the colonial and orientalist conception of purdah.

The populist turn in European and North American politics over the last few years contains elements of nativism which have broadly religious elements. Significantly, some elements of this discourse make an explicit contrast between the concept of indigenous European Christian culture ("civilisation") and the external threat of Islam, as documented in the volume edited by Marzouki et al. (2016). While it would be wrong to concede that the extreme right is sweeping its way to power across the globethere have been setbacks in France, Holland, and other countries-such parties have come to power or have major influence in Eastern Europe and the former Soviet Union. In England, some minority elements on the far right, such as the English Defence League and Britain First, explicitly take a stance against what they perceive as the Islamification of the UK and define themselves as "Christian". Immigration became a highly salient issue in British politics at general elections in 2010 and 2015 and in the referendum on membership of the EU in 2016. However, an analysis of the impact of religion on the referendum vote by Woodhead and Smith (forthcoming) suggests that the nativism in the pro-Brexit vote included a relatively weak and vague attachment to the Church of England as a part of traditional English culture, rather than a strong commitment to Christian belief or church institutions or a focused hostility towards other faiths. Their analysis shows how $67 \%$ of Church of England affiliates and about $55 \%$ of regular churchgoers voted to leave the EU, but that this religious identity factor holds when controlled for other demographic variables. English evangelicals, however, appeared to be quite firmly in the Remain camp.

This, then, is the political, ethno-religious, and socio-cultural context in which British evangelicals have needed to come to terms with the presence of other minority faith communities in their society and their entanglement 
with them. We now present data that throws some light on the dynamics of this process of interaction.

\section{The Survey}

The research evidence comes from of a five-year programme involving a panel survey of self-defined evangelical Christians sponsored by the Evangelical Alliance (2011-2016) and managed by the author of this paper, the first waves of which are reported in Smith (2015). Quantitative research data on evangelical Christians in the UK is extremely hard to find, as the category 'evangelical' (or synonyms such as 'born again' or 'bible believing') has rarely if ever been used in representative sample surveys of the general population. A search of the ESRC UK Data service Discover Variable and question bank reveals only one survey in the current century, the Northern Ireland Life and Times Survey 2004, when a question using the word "evangelical" has been used. It is therefore impossible to enumerate with any degree of confidence the number of evangelical Christians in the UK, the more so because the term has fuzzy boundaries, intersects with a wide range of churches and denominations, and is both changing and often contested in terms of doctrinal 'purity' within the movement (Warner 2007).

Our findings are drawn from a wave of a series of panel surveys entitled "Religions, Belief and Unbelief" carried out in August 2016 and results are based on the replies of 1330 self-identifying evangelicals living in the UK. It is an opportunity sample of Christians recruited through the Alliance's membership and social media networks. Although it cannot be taken as representative of any defined population of UK evangelicals, the demographic profile is consistent with that of earlier waves and the proportion of 'repeating' panel members is in the order of $75 \%$. Of this 
sample, 92\% identify their ethnicity as "White British" and 94\% were UKborn. They have a high average age, with 56\% having been born before $1960,30 \%$ in the 1960 s or 1970 s, and only $14 \%$ since 1980 . They tend to be committed and active Christians and regular churchgoers, and they are drawn from a wide range of Christian denominations, including at least a third who belong to the Church of England. The fact that the sample is compiled via Evangelical Alliance networks, and that the author has longterm 'insider knowledge' of evangelical churches and organizations, gives us a fair degree of confidence that the sample captures the views of the 'committed and activist core' of the evangelical movement in England.

Although a specific question about social class was not asked in this particular wave, it is clear from earlier survey waves (reported in Smith 2015, 21-22) that the panel was predominantly middle to upper class. In the 'Working faithfully?' survey in May 2013, 24\% were higher professionals and a further $47 \%$ intermediate professionals. In the 'Do we value education?' survey in November 2012, 70\% had a university degree and $41 \%$ had postgraduate qualifications. Given that the proportion of 'practising Christians' is known to be significantly higher among Social Grades A, B, and C1 (professional and non-manual workers) than among C2, D, and E groups (manual, semi and unskilled workers) (ComRes and Evangelical Alliance 2017), this probably reflects the socio-economic profile of evangelicals in Britain more generally. While no question about political affiliation was asked in March 2016, an earlier wave of the survey immediately after the May 2015 general election found that 31\% of English evangelicals voted Conservative, 25\% Labour, 17\% Liberal Democrat, $11.5 \%$ UKIP, and 8\% Green. 


\section{Findings}

\section{Theology of Religions}

First of all, the vast majority of British evangelicals maintain an exclusivist theology which firmly insists that Jesus Christ is the only way of salvation. In this they contrast with many other Christians who hold a more inclusive, pluralist, or even universalist view.

In a question specifically used because it could be compared with an earlier YouGov survey (2014) by Woodhead, over 80\% (of 1245 who answered the question) were clear in their understanding that Jesus is the only way of salvation and $84 \%$ thought Christianity is the only path to God (compared to $28 \%$ of 1498 Anglican clergy surveyed in 2014; see Table $1^{2}$ ).

\begin{tabular}{|l|l|l|}
\hline & $\begin{array}{l}\text { EVANGELICALS } \\
\text { (EA 2016) }\end{array}$ & $\begin{array}{l}\text { ANGLICAN CLERGY } \\
\text { (YOUGOV 2014) }\end{array}$ \\
\hline Christianity is the only path to God. & $84 \%$ & $28 \%$ \\
\hline $\begin{array}{l}\text { Christianity is the best path to God, } \\
\text { but other religions may offer paths as } \\
\text { well. }\end{array}$ & $9 \%$ & $44 \%$ \\
\hline $\begin{array}{l}\text { All the major world religions offer } \\
\text { paths to God. }\end{array}$ & $1 \%$ & $13 \%$ \\
\hline $\begin{array}{l}\text { People can find their own paths to } \\
\text { God, whether inside or outside a } \\
\text { world religion. }\end{array}$ & $1 \%$ & $11 \%$ \\
\hline Other & $4 \%$ & $4 \%$ \\
\hline Don't know & $0 \%$ & $1 \%$ \\
\hline N answered question & 1022 & 1498 \\
\hline
\end{tabular}

TABLE 1 "Which of the following statements is closest to your understanding of other religions?"

2 All the tables appearing in the paper have been created by the author from original survey data. In some cases rounding errors result in total percentages not exactly equal to $100 \%$. 
Furthermore, when asked to decide between four possible theological positions framed in terms expressed in language familiar to the Christian sub-culture, $81 \%$ of the evangelicals opted for the exclusivist "Jesus is the only way of salvation-all those who have not put their faith in Him will not enter into eternal life" (see Table 2). $12 \%$ of the panel preferred a more inclusive and biblically based statement (Acts 10:35): "Because of what Jesus has done, God accepts people from every faith community who fear Him and do what is right". Only $2 \%$ had a pluralist view ("There are many different ways to God, all valid and able to bring salvation.") and $1.5 \%$ a universalist one ("God's love and mercy is so vast that ultimately everyone will receive the gift of eternal life").

\begin{tabular}{|l|l|l|}
\hline $\begin{array}{l}\text { God's love and mercy is so vast that ultimately everyone will } \\
\text { receive the gift of eternal life. }\end{array}$ & $1.5 \%$ & \\
\hline $\begin{array}{l}\text { There are many different ways to God, all valid and able to } \\
\text { bring salvation. }\end{array}$ & $1.9 \%$ & \\
\hline $\begin{array}{l}\text { Because of what Jesus has done, God accepts people from ev- } \\
\text { ery faith community who fear Him and do what is right. }\end{array}$ & $12.2 \%$ & $80.7 \%$ \\
\hline $\begin{array}{l}\text { Jesus is the only way of salvation-all those who have not put } \\
\text { their faith in Him will not enter into eternal life. }\end{array}$ & $3.6 \%$ & 1245 \\
\hline Can't decide. & & \\
\hline N answered question & & \\
\hline
\end{tabular}

TABLE 2 "Which of the following comes closest to your view of Christianity and other religions? Please select one only."

In contrast, only $44 \%$ of the 159 respondents who were excluded from most of the analysis because they were not clearly self-defined evangelicals opted for the exclusivist view.

A cross-tabulation analysis testing statistical significance by Chi Square suggested denominational background was also important. While $91 \%$ of Presbyterians (mostly living in Scotland or Northern Ireland) endorsed the exclusivist view, only $76 \%$ of Anglican evangelicals and $73 \%$ of Free Church 
ones did so. Church Leaders (76\%) were slightly though significantly $(\mathrm{P}<.05)$ less likely than non-leaders (82\%) to take the exclusivist line, but the most noticeable and significant difference $(P<.001)$ was between the $81 \%$ of selfdefined evangelicals and the 44\% figure for the 158 respondents who were not clearly evangelical.

In open-ended responses and comments, a wide range of theological expressions were expressed. At one extreme were exclusivist statements, such as the following:

We are of 'another King' (Acts 7) while everyone else in the world-secular or religious-are of the kingdom of the world, ultimately ruled by Satan, so we cannot expect to see eye to eye with them. In fact, a Muslim and a secularist have more in common with each other than with a member of the kingdom of God. ${ }^{3}$

Churches and ministers getting involved with Islamic groups are wrong. We do not worship the same God, and any minister who agrees that we do in order to appease Muslims is plain wrong. How can we worship the same God if we believe Jesus is God and Muslims believe him to be simply a prophet? Jesus is Lord!

We must recognize the demonic power behind the two thought movements you mention (Islam and Secularism).

Confusion today arises from the apparent similarity between some of the teachings of different faiths and of no faith. Many of these faiths appear

3 Quotes from the survey were corrected for typos and errors in punctuation to make them more easily readable. 
to offer a similar code for living but each has a different motivation, whether that motivation be through a striving to earn points, to achieve a blissful state of calm or even out of fear. Only my faith offers a personal relationship with a living Saviour.

I have seen several cases of young people that I work with where they describe themselves as Christian and... e.g. Buddhist. This has proven slightly alarming to me as I don't believe that Christianity can be followed alongside other religious beliefs. Religious pluralism is not such a great challenge. No other faith has the beauty of Christ to commend it.

Christ as the only way to salvation and eternal life is the distinguishing feature of Christianity; an exclusiveness which those of other faiths, and of none, find repugnant.

On the other hand, several respondents expressed views which were much more inclusive and eirenic, such as

My view would be that Jews \& Muslims seek to serve the same God as Christians but their understanding of His character \& nature are different. We therefore have some common ground on which to have meaningful dialogue.

"No other name" is what Christianity teaches but as I gain more understanding of other faiths, I become more tolerant and suspect God may well judge others of different faiths more lovingly than we might otherwise realize. 
I think sometimes Christians can be unnecessarily fearful of the power of other faiths, when they should be more confident in who God is, knowing that He loves all that He has made, including those of other faiths. Christians should have more confidence in God and who He is, so that dialogue can be loving and can honour those who at this stage have a different belief. Secularism is so based in humanism and pride that I think that it is more of an opponent to Christianity than other faiths as it can be aggressive towards those who believe.

Many Christians are scared of the influence of other faiths. God is able to sort it out!

I love diversity and believe that Jesus did too. However, we need to stick by Jesus and love as he did. He knew how to love and to stick by his principles at the same time. This is something sadly we find so difficult.

I live and work in London, perhaps the world's most multi-cultural city, and that probably colours my views. My overriding philosophy is that we should live at peace with our neighbours, and that includes respecting their right to adhere to a different (or no) faith. I am very willing to speak about my faith and to let it be known that I am a practising Christian, but I do not seek to convince others unless they ask, or are in some form of distress where I think Christian love would help.

God and the Gospel are not at risk from secularism or religious pluralism, my God doesn't need to me to defend him-he is much bigger than that and the whole of history is on his side. I do not need to be anxious and come out fighting for my corner. I need to live such a good life (of love, 
including a passion for justice for all) that the 'pagans' give glory to God the Father.

Most common of all were nuanced voices which placed theological clarity and Christian distinctiveness alongside a welcome for religious diversity, liberty of belief, and tolerance, such as:

I am fiercely convinced of the claims of Jesus to be truth, but this leads me to humbly respect and honour those of other convictions whilst fervently praying and hoping for them to see the truth for themselves. It means I must be as gentle as a dove (beyond reproach) in my behaviour and attitudes whilst also as crafty as a fox in helping others see the reality of God in Jesus, through the Holy Spirit.

It is good to know what others believe and to respect them. It is good to have friends who think differently and to develop friendships where it is possible to speak about these things. And everything we do should be done with the intention of honouring others. This doesn't mean teaching that all faiths are equal or finding the lowest common denominator-or assuming that secularism is the neutral ground! People should be free to choose-having heard from people who really believe certain views (not just learning the facts and rituals in class!) and honored in their choice. They should also be allowed to question and to develop their own world view. Eating with people of other faiths is good (as the Archbishop has just done)-but sharing in a multi faith service sends out mixed messages.

Religious pluralism as understood 'all religions are valid and all lead in some way to God' is NOT what biblical Christianity believes. But a pluralist society is a wonderfully enriching place to live for Jesus and appreciate the 
variety of cultures of humankind and discern in every group some hints of the Spirit at work. Where He is we should be pleased to be also.

I think that God will accept into His kingdom some who are ignorant of Christ on the basis of his sacrifice and their faithfulness to the light they have received (such as the Old Testament saints). However, I believe this applies to relatively few in practice because there are few who truly, 'fear Him and do what is right'. For most people it is only responding the gospel which brings this about.

We should only engage with those of other faiths in order to show love, help and encouragement to them. We should not engage in worship with them. [But it is] culturally wonderful.

And at least one respondent suggested it depends on which type of religion is in question:

I would make a distinction between the Monotheistic religions such as Islam \& Judaism and the polytheistic religions such as Hinduism.

Exploring this idea a little further, one pair of questions towards the end of the survey asked how far respondents agreed that Christians and Muslims I Jews both pray to the one true God (or the same God). In the case of Muslims, only $16 \%$ of evangelicals agreed or strongly agreed, while as many as $78 \%$ agreed or strongly agreed Jews do so. Similarly, while $40 \%$ agreed or strongly agreed Muslims and Christians share a similar set of moral values, $89 \%$ thought Jews did so. Clearly, the common heritage of the Abrahamic faiths does not count for as much as the tradition passed from 
Judaism to Christianity via the Hebrew Scriptures. Thus, Islam is more likely to be seen as theologically alien.

In an attempt to ground these views in the knowledge base of respondents about specific religions, our survey asked: "How much do you know about each of these religions?" Figure 1 shows that respondents are most likely to have gathered a good knowledge of Catholicism, followed by Judaism and then Islam. Around a third would like to improve their knowledge of Sikhism, Orthodox Christianity, and traditional religions, but there is some resistance to finding out more about paganism and New Age spiritualities. It is not easy to interpret the meanings of these statistics other than that there is some openness to explore religions in the Abrahamic traditions and some reluctance to investigate emerging 'competitors' in the contemporary religious marketplace.

\section{Relationships with Other Faith Communities}

A batch of Likert-type attitude scales, with five points ranging from "strongly agree" to "strongly disagree" about relationships with other religions (see Table 3), indicated a strong consensus among evangelicals towards missionary outreach and evangelism. 99\% believed Christians should share the gospel with those of other faiths, and 92\% that they should invite people from other faith communities to visit their churches. However, this does not entail crude and heavy-handed proselytism, but for $88 \%$ is based on friendship, for $85 \%$ can include dialogue, and for $82 \%$ means working in partnership on projects and issues. Around two thirds think they should visit the buildings of other faith communities, and only $30 \%$ take the view that Islam, Hinduism and Sikhism are of the devil-a view which $47 \%$ find too extreme. Only $22 \%$ thought Christians should oppose 


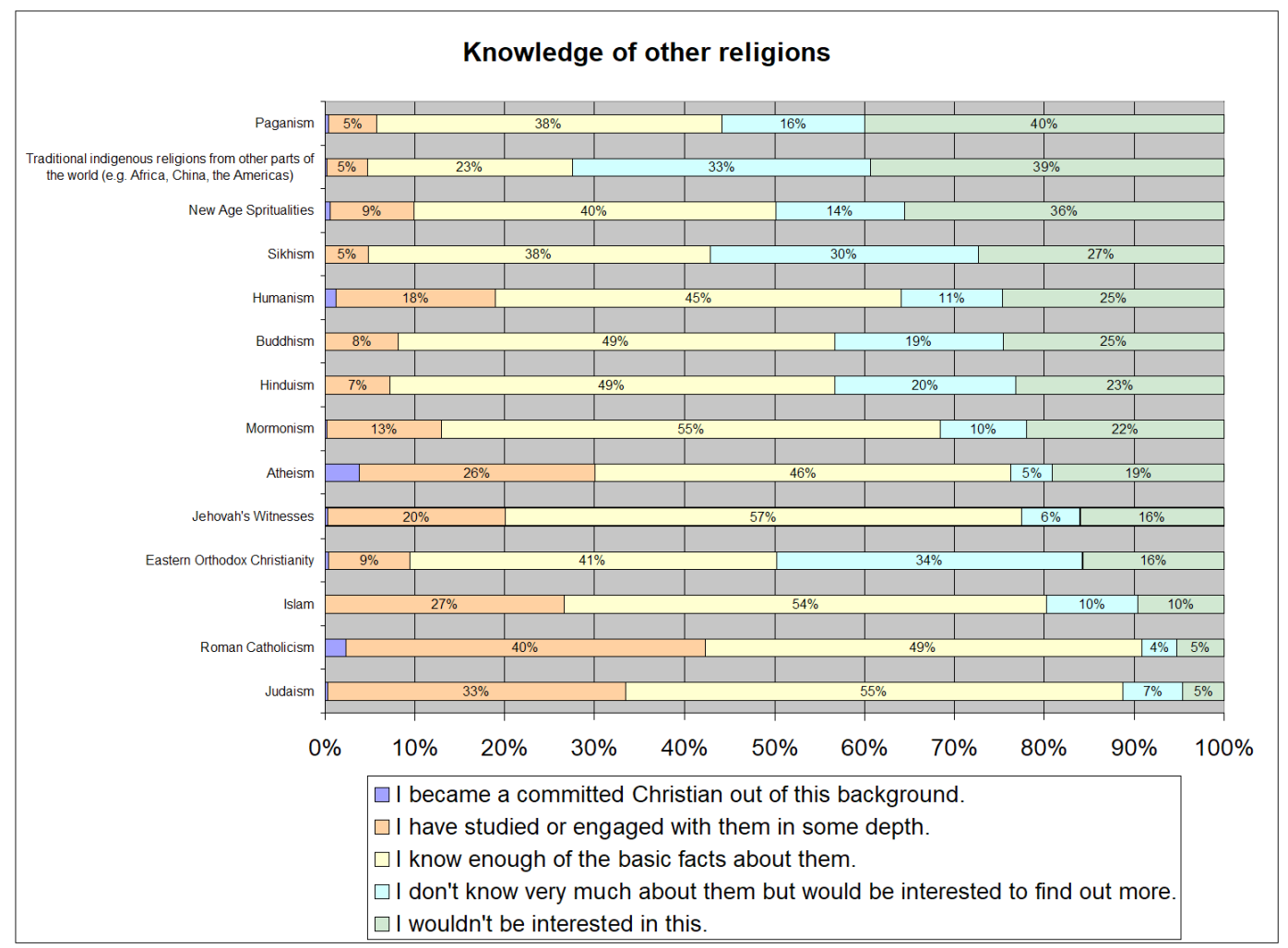

FIGURE 1 Evangelicals' background knowledge of other religions

the building of mosques or temples in their neighbourhood. Only $28 \%$ agree that Christians who are present in the activities of other faith communities are at risk spiritually. On the other hand, only $27 \%$ have been involved in interfaith events and only $26 \%$ agree that Christians should be willing to take part in multi-faith events where each community offers its own form of scripture reading prayer or worship. All this suggests strong support for a particularistic view of the truth of Christian belief and worship practice, coupled with a generous hospitable view of members of other faith communities, albeit on the presumption that they are objects of missionary concern as "not yet Christians". 


\begin{tabular}{|c|c|c|c|c|c|c|}
\hline $\begin{array}{l}\text { HOW FAR DO YOU } \\
\text { AGREE...? }\end{array}$ & $\begin{array}{l}\text { STRONG- } \\
\text { LY AGREE }\end{array}$ & AGREE & $\begin{array}{l}\text { NEITHER } \\
\text { A NOR } \\
\text { DA (OR } \\
\text { DON'T } \\
\text { KNOW) } \\
\end{array}$ & $\begin{array}{l}\text { DIS- } \\
\text { AGREE }\end{array}$ & $\begin{array}{l}\text { STRONG- } \\
\text { LY DIS- } \\
\text { AGREE }\end{array}$ & $\begin{array}{l}\text { STRONG- } \\
\text { LY AGREE } \\
+ \text { AGREE }\end{array}$ \\
\hline $\begin{array}{l}\text { Christians should } \\
\text { share the gospel with } \\
\text { those of other faiths. }\end{array}$ & $63 \%$ & $35 \%$ & $1 \%$ & $0 \%$ & $0 \%$ & $99 \%$ \\
\hline $\begin{array}{l}\text { Christians should in- } \\
\text { vite people from oth- } \\
\text { er faith communities } \\
\text { to visit their church- } \\
\text { es. }\end{array}$ & $35 \%$ & $57 \%$ & $7 \%$ & $1 \%$ & $1 \%$ & $92 \%$ \\
\hline $\begin{array}{l}\text { Christians should be- } \\
\text { friend and listen to } \\
\text { people of other faiths } \\
\text { before jumping in to } \\
\text { proclaim the gospel } \\
\text { to them. }\end{array}$ & $36 \%$ & $53 \%$ & $8 \%$ & $3 \%$ & $1 \%$ & $88 \%$ \\
\hline $\begin{array}{l}\text { Christians should be } \\
\text { actively involved in } \\
\text { religious dialogue } \\
\text { with people of other } \\
\text { faiths. }\end{array}$ & $32 \%$ & $53 \%$ & $11 \%$ & $3 \%$ & $1 \%$ & $85 \%$ \\
\hline $\begin{array}{l}\text { Christians should } \\
\text { gain some under- } \\
\text { standing of other } \\
\text { faiths before sharing } \\
\text { the gospel with their } \\
\text { adherents. }\end{array}$ & $26 \%$ & $57 \%$ & $11 \%$ & $5 \%$ & $1 \%$ & $83 \%$ \\
\hline $\begin{array}{l}\text { Christians should } \\
\text { work together with } \\
\text { other faith commu- } \\
\text { nities on social proj- } \\
\text { ects and political is- } \\
\text { sues. }\end{array}$ & $25 \%$ & $57 \%$ & $14 \%$ & $3 \%$ & $1 \%$ & $82 \%$ \\
\hline $\begin{array}{l}\text { Christians should } \\
\text { take the opportuni- } \\
\text { ties they are given to } \\
\text { visit mosques, syna- } \\
\text { gogues, temples and } \\
\text { gurdwaras. }\end{array}$ & $15 \%$ & $51 \%$ & $24 \%$ & $8 \%$ & $3 \%$ & $65 \%$ \\
\hline $\begin{array}{l}\text { Britain is an essen- } \\
\text { tially secular country. }\end{array}$ & $9 \%$ & $52 \%$ & $22 \%$ & $17 \%$ & $1 \%$ & $61 \%$ \\
\hline $\begin{array}{l}\text { Some Christians } \\
\text { teach that "Is- } \\
\text { lam, Hinduism and } \\
\text { Sikhism are of the } \\
\text { devil"-I think that } \\
\text { view is too extreme. }\end{array}$ & $12 \%$ & $35 \%$ & $23 \%$ & $22 \%$ & $8 \%$ & $47 \%$ \\
\hline $\begin{array}{l}\text { Religion is becom- } \\
\text { ing more, rather than } \\
\text { less, important in } \\
\text { public life. }\end{array}$ & $6 \%$ & $30 \%$ & $22 \%$ & $34 \%$ & $7 \%$ & $37 \%$ \\
\hline
\end{tabular}




\begin{tabular}{|c|c|c|c|c|c|c|}
\hline $\begin{array}{l}\text { HOW FAR DO YOU } \\
\text { AGREE...? }\end{array}$ & $\begin{array}{l}\text { STRONG- } \\
\text { LY AGREE }\end{array}$ & AGREE & $\begin{array}{l}\text { NEITHER } \\
\text { A NOR } \\
\text { DA (OR } \\
\text { DON'T } \\
\text { KNOW) }\end{array}$ & $\begin{array}{l}\text { DIS- } \\
\text { AGREE }\end{array}$ & $\begin{array}{l}\text { STRONG- } \\
\text { LY DIS- } \\
\text { AGREE }\end{array}$ & $\begin{array}{l}\text { STRONG- } \\
\text { LY AGREE } \\
\text { + AGREE }\end{array}$ \\
\hline $\begin{array}{l}\text { Religion tends to di- } \\
\text { vide communities. }\end{array}$ & $3 \%$ & $34 \%$ & $27 \%$ & $30 \%$ & $5 \%$ & $37 \%$ \\
\hline $\begin{array}{l}\text { Britain is not so much } \\
\text { a secular country as } \\
\text { a tolerant, religiously } \\
\text { plural one. }\end{array}$ & $2 \%$ & $33 \%$ & $28 \%$ & $32 \%$ & $4 \%$ & $36 \%$ \\
\hline $\begin{array}{l}\text { Growing religious di- } \\
\text { versity has enriched } \\
\text { British society }\end{array}$ & $4 \%$ & $30 \%$ & $32 \%$ & $24 \%$ & $10 \%$ & $34 \%$ \\
\hline $\begin{array}{l}\text { Christians who are } \\
\text { present in the activ- } \\
\text { ities of other faith } \\
\text { communities are at } \\
\text { risk spiritually. }\end{array}$ & $3 \%$ & $24 \%$ & $33 \%$ & $30 \%$ & $9 \%$ & $28 \%$ \\
\hline $\begin{array}{l}\text { I personally have } \\
\text { been involved in local } \\
\text { interfaith activities } \\
\text { and events. }\end{array}$ & $6 \%$ & $21 \%$ & $21 \%$ & $39 \%$ & $14 \%$ & $27 \%$ \\
\hline $\begin{array}{l}\text { Christians should be } \\
\text { willing to take part } \\
\text { in multi-faith events } \\
\text { where each commu- } \\
\text { nity offers its own } \\
\text { form of scripture } \\
\text { reading prayer or } \\
\text { worship. }\end{array}$ & $5 \%$ & $21 \%$ & $26 \%$ & $32 \%$ & $16 \%$ & $26 \%$ \\
\hline $\begin{array}{l}\text { Britain is essentially } \\
\text { a Christian country. }\end{array}$ & $3 \%$ & $19 \%$ & $18 \%$ & $47 \%$ & $12 \%$ & $22 \%$ \\
\hline $\begin{array}{l}\text { Christians should op- } \\
\text { pose the building of } \\
\text { mosques or temples } \\
\text { in their neighbour- } \\
\text { hood. }\end{array}$ & $6 \%$ & $16 \%$ & $36 \%$ & $31 \%$ & $11 \%$ & $22 \%$ \\
\hline \multicolumn{6}{|l|}{$\mathrm{N}$ : answered question } & 1253 \\
\hline \multicolumn{6}{|l|}{ skipped question } & 77 \\
\hline
\end{tabular}

TABLE 3 Evangelicals' views of other religions.

Statements about the reality of Britain as a religiously diverse society elicited a range of different responses, roughly splitting the panel into three, with one third positively disposed towards diversity, a third having reservations, and a third undecided. 34\% agreed that Growing religious 
diversity has enriched British society, and 37\% that Religion is becoming more, rather than less, important in public life and Religion tends to divide communities. A similar number (36\%) agreed that Britain is not so much a secular country as a tolerant, religiously plural one. In counterpoint, 61\% agreed Britain is an essentially secular country, alongside $22 \%$ believing that Britain is essentially a Christian country. One may interpret these views as a mark of uncertainty in a period of religious and cultural change and a playing out of various images in the evangelical mind of how British society once (allegedly) was, is now, and how it ever ought to be.

The cross-tabulation of these responses by some of the key demographic variables within the panel produced some significant differences (which are detailed in Table 6 in the Appendix). Denominational background (and its associated theological or cultural stance) accounted for the most consistent patterns. Broadly speaking, Presbyterians and Pentecostals held the most conservative and exclusivist views and Anglicans and Free Church members the most inclusive ones. Also, the non-evangelical respondents were more liberal and inclusive in their view of other faiths and religious diversity. On many statements, age was a significant factor, with older people tending towards more conservative views and younger ones more likely to celebrate religious diversity (though they were more likely to agree that other faiths were "of the devil", suggesting a less nuanced youthful theology). Women were also more likely to be more inclusive (or less certain) than men.

We also asked the panel to rank some of the most important factors which could have contributed to secularisation ${ }^{4}$ over the last century. Only $2 \%$ considered the growth of non-Christian faiths the most important factor

4 The question asked about secularisation in this way: "There is strong evidence that the proportion of people in the UK attending church, believing in God and following Jesus has declined over the last century. It also seems clear that the influence of the Church in our 
(and $17 \%$ that this was in some way important). This compared with $31 \%$ who saw consumerism and individualism as the most important factor and $26 \%$ who thought it was "our failure to share the gospel".

Those who made open-ended statements about religious and cultural diversity mostly found it a cause for celebration, some as an opportunity for mission and evangelism:

Britain's religious mixture is the greatest evangelistic opportunity this country has known since Christianity first came here.

Although the dangers of syncretism are grave and prevalent, and the challenges of witnessing in the so called 'post-Christian' West are complex and real, believers in the UK and Europe have an unprecedented opportunity to advance the gospel in societies which are au fait with religious pluralism. A secular state need not be a threat to Christianity.

culture is much reduced. Many factors could have contributed to this secularisation. Which of the following do you think have been most important?"

Answer options:

The challenge presented by science, such as the theory of evolution

The breakdown of family and community life

The problem of suffering, such as the world wars and the Holocaust

The influence of liberal theology

Internal conflicts and scandals in the Church

The growth of non-Christian faiths

Consumerism and individualism

Our failure to preach and share the gospel

Other (please specify)

each to be rated in a grid as

Most important of all (tick only one in this column)

Very important

Important

Not very important

Not at all important

Don't Know 
It is worth pointing out that many Christians feel that the presence of other faiths in our society has helped to put faith back into mainstream consciousness, and enabled Christian witness to a considerable degree. (Something different from saying it has enriched our culture, as one of your questions put it).

I think a confident and welcoming church community has nothing to fear from religious pluralism and 'secularization'. In my experience, the Church seems to be doing a bit better in the multicultural environments I know of, compared to the less diverse communities I'm familiar with.

Religious pluralism is good if it means we can better understand one another and the multiplicity of cultures in the UK. The multi-faith environment is providential and is a real challenge and opportunity for Christians. It provides a chance to think seriously about how the gospel challenges all cultures including that of Christendom Britain and to sharpen our apologetics and presentation of the gospel. At the same time it challenges us to befriend and work alongside those of other faiths, sharing Christ's love and recognizing common humanity and citizenship.

Religious pluralism should be grasped by Christians as a bridge for promoting discussion of faith in wider society, and recognizing the importance of faith values for those who hold them.

I am impressed by reports from such mixed towns as Luton where people of faith work together to support one another when the BNP [the extreme right wing British National Party, G.S.] (and similar) try to stir up religious and racial hatred. 
A number of respondents stressed that good, friendly relationships were essential for effective mission:

A lot of it comes down to attitude. A gracious, genuine, respectful attitude would go a long way to building up communities where faith can be celebrated, can be allowed. Where we can share our lives together and learn from each other. It's pretty hard for the gospel to have much meaning to those around us if we don't have good relationships with the people around us.

I believe Christians need to 'earn the right' to enter into dialogue with people over what they believe. Mostly this comes out of friendships and acts of love. I do believe we should seek to communicate the truth, but in a sensitive manner and out of respect for others. I feel some preachers don't think they are sharing the gospel unless they are being offensive and getting a reaction!! I think evangelicals have a tendency to try and oversimplify matters and try to make everything black and white!!

As Christians we have a duty to speak the truth on love. We shouldn't retreat into a Christian ghetto but be willing to carry Jesus into the world we live. We don't have to fear those who are different. We need to show the love of Jesus. That means accepting those into our country suffering from persecution and fleeing war. Sadly some Christians are so afraid of those who are different that they are afraid to hold out the hand of help to refugees. This is not showing the love of Jesus.

I believe strongly in freedom of speech, even if what is said is offensive to some. However, I believe Christians should strongly avoid offensive 
language; we should speak the truth in love. Some Christians do the faith a disservice by the harshness of their presentation.

There were numerous comments about the possibility of living and working for common goals without demanding Christian privilege in a multi-faith society:

It's important we get to know people of other faiths $\&$ that we have more understanding of other faiths. Increasingly Islam \& Christianity are being set up as opposed to one another $\&$ we need to befriend our local Muslim communities to show what a lie this is.

Please distinguish carefully between inter-faith and multi-faith. We live in a multi-faith universe and can cooperate where appropriate.

It is silly to be anxious about pluralism. True Christian faith flourishes in a pluralistic environment-indeed that's how Christian faith began in Roman times. Nor should we try to prop ourselves up by seeking institutional favoritism towards the church. We should be confident in the truth and power of Jesus as Lord, and as much be advocates for the liberties of other faiths (e.g against Islamophobia) as for our own. I believe there can be good co-operation between faith groups, against secular humanism. A good example was the recent Parliamentary debate on the right to die, where there was co-operation between most evangelicals, Roman Catholics, Orthodox Jews \& Muslims.

Loving each other in community when we strongly disagree with each other's faith is a challenge we must face. This is not the same as modifying or blending each other's beliefs into an amorphous, meaningless 'new/ 
non-religion'; neither does it mean intimidating each other to keep quiet. Sharing life and developing relationships with people of other faiths creates opportunity for meaningful faith conversations. As a Christian, I do not feel that my faith is threatened in any way; it 'holds its own', because it is true. I find other faiths interesting, and enjoy learning about them.

Throughout scripture we find the principle that the "stranger and alien" be shown respect and hospitality, whatever their faith. In the New Testament we find the instruction to share the gospel with all, but not to force any to believe.

No faith has the automatic right to be promoted by the authorities; all faiths have the right to be protected by the authorities except where they are clearly acting against the common good.

Christians need to respect people who follow other religions and to share love and the Christian faith with them. There needs to be freedom of speech and freedom to express religious views whilst respecting others. Inciting to hatred or violence is always wrong. It is not possible to give Christians the platforms they would like without giving them to other religions. Therefore whenever we stand for a Christian "right" we need to ask ourselves if we would give that right to others.

Christians should be better educated in other religions to better interact and witness socially.

A few expressed the idea that Christians were facing discrimination: 
As evangelicals we can be strong and confident as we respectfully talk and work with those of other world views. Other faiths seem to be allowed more freedom than Christians \& given special treatment; e.g. local government gave a piece of land to a Hindu group to build a temple for $£ 1$; churches would not be given land to build a place of worship.

It is OK to attack Christianity and to a certain extent other religions apart from Islam, which has become untouchable because of fear of recrimination. It seems to me that many would not criticise those of nonChristian beliefs when they are quick to condemn Christians for similar actions. Of course, we practice love and not hate, and those who criticise know they will not get the same sort of flak from us as they would get from others!

I am fed up of one particular religion getting special treatment. As Christians we are being marginalised by mainstream media and the government. However, Islam seems to be given carte blanche to say and do whatever it likes.

\section{Although this was sometimes contradicted:}

I think there is a lot of hysteria about 'persecution' of Christians largely whipped by a press that is indifferent to Christian faith. I believe that we are called to be peacemakers in a society that is increasingly losing the ability to live at peace with itself and this means that we need to listen more and speak less and above all create outward looking gatherings of Jesus followers who live by his ethic and values in a confused world. 
And a few believed that multi-culturalism and pluralism had failed or contradicted the heritage of our Christian nation.

Religious pluralism is clearly failing and is counterproductive to its intention-i.e. leads to the creation of 'ghettos' and not effective integration.

The UK is a Christian country and the Christian faith and teachings should always be upheld over everything else.

\section{Children and Education}

The same pattern of dynamics versus stability can be seen in our evangelicals view of children and education (see Table 4). While over three quarters approve of a multi-faith religious education, two thirds think this could be confusing for children, and less than half that Children benefit from growing up in a multi-faith environment. 64\% agree that Mainstream state schools have an overwhelmingly secular ethos which damages children's spiritual development, and 54\% support the right of parents to send their children to single faith schools. A small majority agree that Statemaintained education should be distinctly Christian in character, in line with what is still a legal requirement under the School Standards and Framework Act 1998 that all students in England and Wales participate in a daily act of worship, which is to be "wholly or mainly of a broadly Christian character" (unless the school is a religious one of a different faith tradition). 


\begin{tabular}{|c|c|c|c|c|c|c|}
\hline $\begin{array}{l}\text { CHILDREN TO- } \\
\text { DAY ARE GROW- } \\
\text { ING UP AND GO- } \\
\text { ING TO SCHOOL } \\
\text { IN A RELIGIOUSLY } \\
\text { DIVERSE SOCIETY. } \\
\text { HOW FAR DO YOU } \\
\text { AGREE.....? }\end{array}$ & $\begin{array}{l}\text { STRONG- } \\
\text { LY } \\
\text { AGREE }\end{array}$ & AGREE & $\begin{array}{l}\text { NEITHER } \\
\text { A NOR } \\
\text { DA (OR } \\
\text { DON'T } \\
\text { KNOW) }\end{array}$ & DISAGREE & $\begin{array}{l}\text { STRONG- } \\
\text { LY DIS- } \\
\text { AGREE }\end{array}$ & $\begin{array}{l}\text { STRONG- } \\
\text { LY AGREE } \\
\text { + AGREE }\end{array}$ \\
\hline $\begin{array}{l}\text { Religious educa- } \\
\text { tion in mainstream } \\
\text { schools should cov- } \\
\text { er a wide range of } \\
\text { faiths. }\end{array}$ & $13 \%$ & $63 \%$ & $12 \%$ & $10 \%$ & $2 \%$ & $76 \%$ \\
\hline $\begin{array}{l}\text { Children today can } \\
\text { be confused and } \\
\text { misled by the vari- } \\
\text { ety of religious be- } \\
\text { liefs they encounter. }\end{array}$ & $15 \%$ & $50 \%$ & $19 \%$ & $15 \%$ & $2 \%$ & $64 \%$ \\
\hline $\begin{array}{l}\text { Mainstream state } \\
\text { schools have an } \\
\text { overwhelmingly sec- } \\
\text { ular ethos which } \\
\text { damages children's } \\
\text { spiritual develop- } \\
\text { ment. }\end{array}$ & $18 \%$ & $46 \%$ & $23 \%$ & $11 \%$ & $2 \%$ & $64 \%$ \\
\hline $\begin{array}{l}\text { Parents should have } \\
\text { the right to send } \\
\text { their children to } \\
\text { schools where ONLY } \\
\text { their own faith is } \\
\text { represented, taught } \\
\text { and practised. }\end{array}$ & $18 \%$ & $36 \%$ & $21 \%$ & $21 \%$ & $4 \%$ & $54 \%$ \\
\hline $\begin{array}{l}\text { State-maintained } \\
\text { education should be } \\
\text { distinctly Christian } \\
\text { in character. }\end{array}$ & $14 \%$ & $38 \%$ & $31 \%$ & $15 \%$ & $2 \%$ & $51 \%$ \\
\hline $\begin{array}{l}\text { Children benefit } \\
\text { from growing up in } \\
\text { a multi-faith envi- } \\
\text { ronment. }\end{array}$ & $7 \%$ & $41 \%$ & $31 \%$ & $16 \%$ & $5 \%$ & $48 \%$ \\
\hline \multicolumn{6}{|l|}{ answered question } & 1209 \\
\hline \multicolumn{6}{|l|}{ skipped question } & 121 \\
\hline
\end{tabular}

TABLE 4 Evangelicals' views on children and education.

The open-ended comments in this section again revealed a wide range of views. On the one hand were those who stressed the difficulty for maintaining an evangelical Christian witness in mainstream education, often arguing that this was the result of aggressive secularist ideology. 
I was a Deputy Headteacher in a multicultural school. I took assemblies but was unable to speak about my faith as I would have liked. Parents, governors, and an atheist headteacher would not have not allowed it.

As an ex-teacher and school governor I think religious pluralism in schools usually presents religions, especially Christianity, as a bland collection of cultural practices without any of the underlying beliefs. There is also a trend to present Islam in an overly benevolent light, especially given its discriminatory nature and violent beginnings and history.

I am a (recently resigned) ex-teacher. Last year I sent a carefully worded email to all staff inviting them to join me in a time of Christian prayer in the newly established, but not publicised, "prayer room". An email followed from upper management stating that the room was for quiet, individual prayer etc etc. I was not formally rebuked-so that I could not complain on discrimination grounds.

I approve of Christian schools but strongly oppose Muslim schools. I grew up in a Muslim country, attending a Christian school. My parents and school made clear to me the truth of Christianity, I chose to follow that path. It seems to me that aggressive secularism tends to be more of an obstacle to Christianity than other religions.

However, there were many more voices approving of multi-faith religious education and the rights of all faith communities to be fully recognized in the education system, arguing that Christian privilege was no longer appropriate. 
As the Head of RE, I was conscious of constant secular opposition, but the Statutory Law, and the Management supported me-on the whole. Muslim scholars were particularly close to me-we showed respect for each other and debated frankly. My relationship with Jewish scholars and Leaders was pleasant and humorous.

I would hesitate to say that a school should be allowed to teach only one religion, because to know about our society is good. However, parents should be able to choose a school where one is especially promoted, i.e. used in worship and taught most.

A balanced religious pluralism as a political ideal is better than aggressive Secularism.

Many within the education field masquerading under various guises would like to eliminate religious teaching altogether as belonging to a bygone age. I support the teaching of other religions so that children have knowledge of what others believe. However, the U.K. having a Christian heritage should mean that the emphasis of religious teaching should be on Christianity, not with a purpose of forcing conversion, but offering full information about the tenets of the faith. It should be possible for children to make an informed decision about the faith they wish to be part of.

People should have the right to choose faith schools, but those schools should teach about other faiths, including atheism.

I would favour removing the privileged position of Christianity from schools. It is time to end the largely Christian act of worship. Because we are now a multi-faith society, I think children should be given the basic 
outlines of other faiths as well as a thorough grounding in the Christian faith (or their own faith if appropriate).

The state needs to be even-handed to all groups, of any kind, who obey the law; this means that ALL religions should have the legal right to run schools that are based on their own faith alone.

There were also a number of personal testimonies about the value of a diverse religious environment:

A multi faith environment helps children to know that being a Christian is a choice and is different from many others. My children are grown up now and are both strong Christians.

I am grateful to live in a city where Christians can go into schools and explain what Christians believe and to interact with pupils.

I feel my children have benefited from growing up and being educated in Leicester, one of the most diverse communities in the UK. They have friends across several cultural and religious groups and share their faith with them through conversation and have invited them to church services. They are not afraid of the unknown, and I believe that it is the way forward for our society.

I believe my own children were blessed to spend their early years in multifaith East London, where religion obviously mattered to all their friends, and their secular primary school did a brilliant job in valuing all the different traditions. That experience gave them a grounding in their own faith community and Christian tradition, where they had to ask serious 
theological questions at an early age. Out of this they both came to a personal faith in Jesus at the appropriate time for them.

\section{Evangelicals, Muslims and Islam}

Finally, a specific set of questions on attitudes towards Islam and Muslims was completed optionally by respondents who had enough energy and interest to continue through to the end of a very long questionnaire. Over 1000 evangelical respondents did so and the findings can be seen in Table 5. The patterns of response show a degree of complexity in the relationship between Christianity and Islam. On the one hand, there is tolerance and support for liberty of belief and practice extended to Muslims. On the other hand, there is some ambivalence and scepticism about what some see as a Muslim attempt to impose their beliefs and institutions, such as sharia courts on British society.

\begin{tabular}{|l|r|r|r|r|r|r|}
\hline & $\begin{array}{l}\text { STRONG- } \\
\text { LY AGREE }\end{array}$ & AGREE & $\begin{array}{l}\text { NEITHER } \\
\text { A NOR } \\
\text { DA }\end{array}$ & $\begin{array}{l}\text { DIS- } \\
\text { AGREE }\end{array}$ & $\begin{array}{l}\text { STRONG- } \\
\text { LY DIS- } \\
\text { AGREE }\end{array}$ & $\begin{array}{l}\text { SA + } \\
\text { AGREE }\end{array}$ \\
\hline $\begin{array}{l}\text { Halal food should } \\
\text { always be labelled } \\
\text { so that people can } \\
\text { choose whether or } \\
\text { not to consume it. }\end{array}$ & $38 \%$ & $51 \%$ & $8 \%$ & $2 \%$ & $1 \%$ & $\mathbf{8 9} \%$ \\
\hline $\begin{array}{l}\text { There should be no } \\
\text { place in the UK legal } \\
\text { system for sharia } \\
\text { law. }\end{array}$ & $59 \%$ & $28 \%$ & $8 \%$ & $3 \%$ & $2 \%$ & $\mathbf{8 7 \%}$ \\
\hline $\begin{array}{l}\text { In certain settings } \\
\text { and roles such as } \\
\text { in courts, or as } \\
\text { teachers or medical } \\
\text { professionals Muslim } \\
\text { women should be } \\
\text { required to uncover } \\
\text { their faces. }\end{array}$ & $41 \%$ & $44 \%$ & $8 \%$ & $5 \%$ & & \\
\hline
\end{tabular}




\begin{tabular}{|c|c|c|c|c|c|c|}
\hline & $\begin{array}{l}\text { STRONG- } \\
\text { LY AGREE }\end{array}$ & AGREE & $\begin{array}{l}\text { NEITHER } \\
\text { A NOR } \\
\text { DA }\end{array}$ & $\begin{array}{l}\text { DIS- } \\
\text { AGREE }\end{array}$ & $\begin{array}{l}\text { STRONG- } \\
\text { LY DIS- } \\
\text { AGREE }\end{array}$ & $\begin{array}{l}\text { SA + } \\
\text { AGREE }\end{array}$ \\
\hline $\begin{array}{l}\text { Christians should } \\
\text { challenge Muslims } \\
\text { about the right of } \\
\text { all people to choose } \\
\text { and change their } \\
\text { faith. }\end{array}$ & $35 \%$ & $48 \%$ & $14 \%$ & $2 \%$ & $0 \%$ & $84 \%$ \\
\hline $\begin{array}{l}\text { Muslims in Britain } \\
\text { should continue } \\
\text { to have the right } \\
\text { to produce and } \\
\text { consume halal food. }\end{array}$ & $16 \%$ & $60 \%$ & $16 \%$ & $5 \%$ & $3 \%$ & $76 \%$ \\
\hline $\begin{array}{l}\text { The Western powers } \\
\text { are right to take } \\
\text { military action } \\
\text { against Da'esh/ } \\
\text { Isis (the so-called } \\
\text { "Islamic State"). }\end{array}$ & $30 \%$ & $42 \%$ & $21 \%$ & $5 \%$ & $2 \%$ & $72 \%$ \\
\hline $\begin{array}{l}\text { Christians should } \\
\text { admire Muslims' } \\
\text { devotion to prayer } \\
\text { and their scriptures. }\end{array}$ & $9 \%$ & $50 \%$ & $24 \%$ & $13 \%$ & $5 \%$ & $59 \%$ \\
\hline $\begin{array}{l}\text { Muslims are aiming } \\
\text { to become the } \\
\text { dominant religion } \\
\text { in Britain and to } \\
\text { impose Islamic rule } \\
\text { in this country. }\end{array}$ & $24 \%$ & $34 \%$ & $24 \%$ & $13 \%$ & $5 \%$ & $58 \%$ \\
\hline $\begin{array}{l}\text { Muslims should have } \\
\text { the right to wear } \\
\text { whatever modest } \\
\text { clothing they wish in } \\
\text { the street, including } \\
\text { the hijab (headscarf) } \\
\text { and niqab (full face } \\
\text { veil). }\end{array}$ & $15 \%$ & $42 \%$ & $18 \%$ & $18 \%$ & $7 \%$ & $57 \%$ \\
\hline $\begin{array}{l}\text { I personally find } \\
\text { it difficult when I } \\
\text { see Muslim women } \\
\text { wearing the niqab } \\
\text { (full face veil). }\end{array}$ & $17 \%$ & $36 \%$ & $18 \%$ & $19 \%$ & $10 \%$ & $53 \%$ \\
\hline $\begin{array}{l}\text { Muslims generally } \\
\text { are well-disposed } \\
\text { towards Christians. }\end{array}$ & $4 \%$ & $39 \%$ & $35 \%$ & $16 \%$ & $5 \%$ & $43 \%$ \\
\hline $\begin{array}{l}\text { Muslims and } \\
\text { Christians share a } \\
\text { similar set of moral } \\
\text { values. }\end{array}$ & $3 \%$ & $37 \%$ & $26 \%$ & $24 \%$ & $10 \%$ & $40 \%$ \\
\hline $\begin{array}{l}\text { Islam is basically a } \\
\text { religion of peace. }\end{array}$ & $3 \%$ & $19 \%$ & $27 \%$ & $30 \%$ & $22 \%$ & $22 \%$ \\
\hline
\end{tabular}




\begin{tabular}{|c|c|c|c|c|c|c|}
\hline & $\begin{array}{l}\text { STRONG- } \\
\text { LY AGREE }\end{array}$ & AGREE & $\begin{array}{l}\text { NEITHER } \\
\text { A NOR } \\
\text { DA }\end{array}$ & $\begin{array}{l}\text { DIS- } \\
\text { AGREE }\end{array}$ & $\begin{array}{l}\text { STRONG- } \\
\text { LY DIS- } \\
\text { AGREE }\end{array}$ & $\begin{array}{l}\text { SA + } \\
\text { AGREE }\end{array}$ \\
\hline $\begin{array}{l}\text { Christians and } \\
\text { Muslims both pray to } \\
\text { the one true God (or } \\
\text { the same God). }\end{array}$ & $3 \%$ & $13 \%$ & $14 \%$ & $22 \%$ & $49 \%$ & $15 \%$ \\
\hline $\begin{array}{l}\text { Christians should } \\
\text { never consume halal } \\
\text { food. }\end{array}$ & $5 \%$ & $9 \%$ & $35 \%$ & $35 \%$ & $17 \%$ & $13 \%$ \\
\hline $\begin{array}{l}\text { Violent extremism is } \\
\text { very common among } \\
\text { Muslims living in } \\
\text { Britain. }\end{array}$ & $3 \%$ & $9 \%$ & $21 \%$ & $49 \%$ & $19 \%$ & $12 \%$ \\
\hline $\begin{array}{l}\text { The UK should allow } \\
\text { Muslims to settle } \\
\text { issues of family law } \\
\text { and inheritance } \\
\text { through their own } \\
\text { courts. }\end{array}$ & $2 \%$ & $5 \%$ & $11 \%$ & $38 \%$ & $44 \%$ & $7 \%$ \\
\hline \multicolumn{6}{|l|}{ answered question } & 1024 \\
\hline skipped question & & & & & & 306 \\
\hline
\end{tabular}

TABLE 5 Evangelicals' attitudes towards Islam and Muslims.

There is widespread support for freedom to produce and consume halal food (provided it is labeled as such) and to wear Islamic dress, though there is some discomfort about the niqab, and $85 \%$ agree that in some social settings Muslim women should not be veiled. Only $22 \%$ agree with the line much promoted by liberal politicians that Islam is basically a religion of peace, yet only $12 \%$ think Violent extremism is very common among Muslims living in Britain. At the same time, 59\% agree Christians should admire Muslims' devotion to prayer and their scriptures.

This ambivalent and nuanced pattern of responses suggests a volatile and dynamic set of attitudes, which in all probability react with the salient issues of the time and the coverage of global, national, and local disputes and conflicts which have a religious dimension or framing in the media. 
More extended comments from respondents reinforce the view that a wide range of views exist among evangelicals, from the exclusive and fearful to a view that is tolerant, broadly inclusive, and sees Muslims as allies against the secular world. It is clear that some evangelicals adopt a narrative which frames Islam as a hostile competitor to Christianity (and the imagined Christian Nation), which in some examples is extreme and verging on the racist, Islamophobic, and paranoid.

We are far too pro liberal, Muslim, atheist, whereas Christianity is attacked \& repressed. Evangelical Christians particularly are those being persecuted for their beliefs.

There is another 2-pronged attack from Islam: 1: raise Islamist extremism and see it condemned as hatred and violence; 2: offer a milder form of Islam as something the authorities would rather tolerate instead. This has led to creeping Islam.

Islam, we are constantly told, is about peace, etc, etc, but the teachings of the Koran does not seem to support this. It would be good for folk to hear the truth about different religions, including Christianity.

I think we need, as a nation, to encourage anything that will reinforce our Christian heritage and not be so afraid of offending those of other faiths, particularly Muslims.

I would ban every Islam(ic) court (we do not want two systems, especially one which is as foul as Islam courts are over women's rights) and every mosque that did not state its message in English, the wearing of clothes that come from the country of origin of these people (they now live in 
Britain and should adopt the style of clothing most dominant in this country). The speaking of English should be compulsory on the streets, roads, lanes etc. of this country so that everyone knows what is going on around them.

As a nation we have made a grave mistake in recent decades by allowing people of alien cultures (religions) to settle and become large minorities which are then considered of equal validity to the Christian tradition and morality, which has been ours for well over 1000 years.

I'm concerned about 'positive discrimination'-e.g. the authorities would be much more careful about offending the Muslim community than they would the Christian community. Perhaps because we would not react as fiercely? An outworking of this in general society is how often the name of Jesus is used as a swear word and nobody reacts. Imagine if the name of Allah was used publicly as a swear word...

Political Correctness has led, and still leads, to an unwillingness to confront issues on religion and morality for fear of upsetting some parts of the community-and sometimes creating violent reaction. For instance, 'Islam is a Religion of Peace' is a mantra often put out by Islam and some Christians and Government. The Koran and the practice of Mohammed and the practice of many Islamic governments contradict this statement in many ways. We must seek to live at peace with all people and to love them and care for them, but not at the expense of facing truth.

In contrast, there are those who hold a view which see Muslims as allies in a shared struggle against aggressive secularism and cultural liberalism. 
I think that secularism is a greater threat to Christianity and religious freedom in the UK than the rise of Islam. I believe it is often easier to speak about faith and find common ground with Muslims than liberal secular humanists.

It is secularists that get hung up about Christmas etc. We find local Muslims have no problem with us celebrating such festivals.

I really do think that Britain is not a Christian country-it is now strongly secular, with vestiges of its Christian heritage. To me it seems that the media uphold secularism, and religions play second fiddle. Christianity and Islam are portrayed in a negative light the majority of the time, and other major world religions are barely mentioned at all.

My Muslim friends are delighted to hear that Christians do not support homosexual practice.

I would be fearful of the type of secularism currently being implemented in France over the burkini ban. It's a dangerous road to go down.

If it allows us to ban burkas with their overtones of Muslim sexual exploitation, we would be better to accept a ban on all religious symbols being worn.

My view would be that Jews \& Muslims seek to serve the same God as Christians but their understanding of His character \& nature are different. We therefore have some common ground on which to have meaningful dialogue. There is also much confusion between culture and religion that needs to be taken into account. 
There were also a small number of comments, presumably from left leaning radical evangelicals, which expressed concern about the conservative views they had found to be dominant in the evangelical world.

It is also interesting that the language of the religious bigots of Hindu 'nationalists' in a place like Nepal is reflected in the language of the religious right in the UK, Christian Concern etc. They use the language of self-defined victimhood to justify their need for supremacy.

Another Christian told me my posts on Facebook about Israeli treatment of Palestinians, and about Brexit, indicated that I was a white-hating antiSemite and then unfriended me...

I don't feel $100 \%$ free when speaking in my home church to express my views on Socialism or Palestine, but in general my Muslim friends accept me for who I am as a Christian.

In fact, the issue of Palestine may be a divisive one within both church and political arenas. $47 \%$ of the evangelical panel agreed or strongly agreed that I believe that the state of Israel is responsible for much of the suffering of the Palestinian people and $86 \%$ that It is possible to criticise Zionism and the actions of the state of Israel without being anti-Semitic. This should not be taken as evidence for widespread anti-Semitic views, since $57 \%$ thought Christians need to repent of a long history of anti-Semitism and 54\% that Jewish people in the UK face serious problems of discrimination and antiSemitism. But only $17 \%$ agreed or strongly agreed that Christians should always support the state of Israel in its conflicts with its enemies. That this is a minority view seems far removed from the widespread extreme 
Christian Zionism that is reported among North American evangelicals (Kidd 2009, 120; Spector 2009).

\section{Conclusion}

The findings presented are from a limited piece of research in one sector of British Christianity. Future comparative research with other denominations, for example among Roman Catholics and the rapidly growing African Pentecostal sector and other ethnic minority congregations, would be extremely useful. Furthermore, it would be of great interest and value to carry out reciprocal work in minority faith communities to discover what Muslims, Hindus, and Sikhs, for example, think about the Christian churches and post-Christendom culture of the UK.

The evidence we have presented shows clearly that evangelicals in the UK do not entirely conform to the stereotype of a conservative evangelicalism that is in alliance with a nationalistic 'religious right' that is portrayed as the norm in the USA and some other parts of the world. While there is an overwhelming theological conviction that Jesus Christ is the only way of salvation, this does not preclude an acceptance or even celebration of contemporary British society as religiously diverse and tolerant. Older people and those from Presbyterian and Pentecostal backgrounds are more likely than Anglicans or Free Church members to hold conservative and exclusivist views. There is evidence that the two historical positions towards Muslims of 'Crusader' and 'Missionary' persist in tension in the British evangelical community, with no overall consensus about an intrinsic and intractable global 'clash of civilisations'. There are also signs, especially among those who are socially, politically, and culturally engaged in religiously diverse (mainly urban) settings, that evangelical Christians 
are coming to terms with profound social and religious change, and see other faith communities simultaneously as competitors and potential collaborators in a secular society.

Evangelicals in the U.K may, however, face something of a parting of the ways in terms of what they should do at this point in history, in the context of polarised debates over Brexit and the evident growth and legitimization of far-right populist discourse, much of which is anti-Islamic in tone and sees perceived 'political correctness' as an attack on free speech. The debates are also influenced by the discourse of the 'culture wars' in the USA and the widespread support of American evangelicals for the Republican Right and Donald Trump. The more open and mission-focused sector of British evangelicals will most likely respond to encouragement to debate and dialogue with Muslims and those of other world faiths. Hopefully they will come to a deeper understanding, a mutual respect, tolerance, and an ability to work together on social and community issues, while remaining clear and distinctive in their religious beliefs and moral values. Within this dynamic, both sides will need to reiterate any individual's right to change their religious affiliation, to convert from one faith to another in either direction without fear or reprisal or hostility. The recent publication by the Evangelical Alliance of "The world on our doorstep" (Hughes 2016) is a useful resource in this regard.

What is more difficult and potentially dangerous is the future for the minority of British evangelicals who adopte the 'Crusader' world view. Wishing them to go away is no solution, yet arguing with them to soften their stance, or asking them to engage in non-polemic dialogues with proponents of other religions is unlikely to be very effective. Some may see such conversations as compromise on the Gospel, or as threatening to their own identity and in response even harden their positions. One can 
only hope and pray that the outcome is not in any measure a replay of the horrific violence of the original medieval Crusades.

\section{Appendix}

\begin{tabular}{|c|c|c|c|c|c|}
\hline $\begin{array}{l}\text { SIGNIFICANT DIF- } \\
\text { FERENCES BE- } \\
\text { TWEEN SUB- } \\
\text { GROUPS ON CHI } \\
\text { SQUARE TESTS. } \\
* * \mathrm{P}<.01 * \mathrm{P}< \\
.05\end{array}$ & GENDER & AGE & LEADER & $\begin{array}{l}\text { DENOMINA- } \\
\text { TION }\end{array}$ & $\begin{array}{l}\text { COMPARED } \\
\text { WITH NON } \\
\text { EVANGELI- } \\
\text { CAL RESPON- } \\
\text { DENTS }\end{array}$ \\
\hline $\begin{array}{l}\text { Christians should } \\
\text { be actively involved } \\
\text { in religious dialogue } \\
\text { with people of other } \\
\text { faiths. }\end{array}$ & NSD & $\begin{array}{r}\text { ** younger } \\
\text { people } \\
\text { agree more }\end{array}$ & NSD & $\begin{array}{r}* \text { Anglicans } \\
\text { agree most } \\
\text { Pentecostals } \\
\text { least }\end{array}$ & $\begin{array}{r}\text { Non-Es agree } \\
\text { more strongly } \\
\text { but NSD }\end{array}$ \\
\hline $\begin{array}{l}\text { Christians should } \\
\text { gain some } \\
\text { understanding } \\
\text { of other faiths } \\
\text { before sharing the } \\
\text { gospel with their } \\
\text { adherents. }\end{array}$ & NSD & $\begin{array}{r}* \text { younger } \\
\text { people } \\
\text { agree more }\end{array}$ & NSD & $\begin{array}{r}* \text { Anglicans } \\
\text { agree most } \\
\text { Pentecostals and } \\
\text { Presbyterians } \\
\text { least }\end{array}$ & $\begin{array}{r}* * \text { Non-Es } \\
\text { agree more } \\
\text { strongly }\end{array}$ \\
\hline $\begin{array}{l}\text { Christians should } \\
\text { work together } \\
\text { with other faith } \\
\text { communities on } \\
\text { social projects and } \\
\text { political issues. }\end{array}$ & NSD & $\begin{array}{l}\text { ** middle } \\
\text { aged group } \\
\text { agree most }\end{array}$ & NSD & $\begin{array}{r}* * \text { Anglicans } \\
\text { agree most } \\
\text { Pentecostals and } \\
\text { Presbyterians } \\
\text { least }\end{array}$ & $\begin{array}{r}\text { ** Non-Es } \\
\text { agree more } \\
\text { strongly }\end{array}$ \\
\hline $\begin{array}{l}\text { Christians } \\
\text { should take the } \\
\text { opportunities } \\
\text { they are given } \\
\text { to visit mosques, } \\
\text { synagogues, } \\
\text { temples and } \\
\text { gurdwaras. }\end{array}$ & NSD & $\begin{array}{r}* * \text { middle } \\
\text { aged group } \\
\text { agree most }\end{array}$ & $\begin{array}{r}* \text { Leaders } \\
\text { agree } \\
\text { more }\end{array}$ & $\begin{array}{r}* * \text { Anglicans } \\
\text { and Free Church } \\
\text { agree most } \\
\text { Pentecostals and } \\
\text { Presbyterians } \\
\text { least }\end{array}$ & $\begin{array}{r}\text { ** Non-Es } \\
\text { agree more } \\
\text { strongly }\end{array}$ \\
\hline $\begin{array}{l}\text { Some Christians } \\
\text { teach that "Islam, } \\
\text { Hinduism and } \\
\text { Sikhism are of } \\
\text { the devil"-I think } \\
\text { that view is too } \\
\text { extreme. }\end{array}$ & $\begin{array}{r}\text { ? More } \\
\text { women } \\
\text { are } \\
\text { uncertain }\end{array}$ & $\begin{array}{r}\text { ** youngest } \\
\text { group } \\
\text { disagree } \\
\text { most }(43 \%)\end{array}$ & $\begin{array}{r}* \text { Leaders } \\
\text { agree } \\
\text { more }\end{array}$ & $\begin{array}{r}\text { **Pentecostals } \\
\text { and } \\
\text { Presbyterians } \\
\text { disagree most }\end{array}$ & $\begin{array}{r}\text { ** Non-Es } \\
\text { agree more } \\
\text { strongly }\end{array}$ \\
\hline
\end{tabular}




\begin{tabular}{|c|c|c|c|c|c|}
\hline $\begin{array}{l}\text { SIGNIFICANT DIF- } \\
\text { FERENCES BE- } \\
\text { TWEEN SUB- } \\
\text { GROUPS ON CHI } \\
\text { SQUARE TESTS. } \\
* * \text { P<.01* P< } \\
.05\end{array}$ & GENDER & AGE & LEADER & $\begin{array}{l}\text { DENOMINA- } \\
\text { TION }\end{array}$ & $\begin{array}{l}\text { COMPARED } \\
\text { WITH NON } \\
\text { EVANGELI- } \\
\text { CAL RESPON- } \\
\text { DENTS }\end{array}$ \\
\hline $\begin{array}{l}\text { Growing religious } \\
\text { diversity has } \\
\text { enriched British } \\
\text { society. }\end{array}$ & $\begin{array}{r}{ }^{*} \text { men } \\
\text { disagree } \\
\text { more }\end{array}$ & $\begin{array}{r}\text { ** younger } \\
\text { people } \\
\text { agree more }\end{array}$ & NSD & $\begin{array}{r}* \text { Anglicans } \\
\text { agree most } \\
\text { Pentecostals } \\
\text { least }\end{array}$ & $\begin{array}{r}* * \text { Non-Es } \\
\text { agree more } \\
\text { strongly }\end{array}$ \\
\hline $\begin{array}{l}\text { Christians who } \\
\text { are present in the } \\
\text { activities of other } \\
\text { faith communities } \\
\text { are at risk } \\
\text { spiritually. }\end{array}$ & $\begin{array}{r}* * \text { more } \\
\text { men } \\
\text { agree }\end{array}$ & NSD & $\begin{array}{r}* \text { Leaders } \\
\text { disagree } \\
\text { more but } \\
\text { many } \\
\text { more } \\
\text { leaders } \\
\text { are } \\
\text { uncertain }\end{array}$ & $\begin{array}{r}\text { **Pentecostals } \\
\text { and } \\
\text { Presbyterians } \\
\text { agree most }\end{array}$ & $\begin{array}{r}* * \text { Non-Es } \\
\text { disagree more } \\
\text { strongly }\end{array}$ \\
\hline $\begin{array}{l}\text { I personally have } \\
\text { been involved in } \\
\text { local interfaith } \\
\text { activities and } \\
\text { events. }\end{array}$ & $\begin{array}{r}* \text { more } \\
\text { men } \\
\text { agree }\end{array}$ & NSD & $\begin{array}{r}\text { ** Leaders } \\
\text { agree } \\
\text { most }\end{array}$ & $\begin{array}{r}\text { ** Presbyterians } \\
\text { and "other" } \\
\text { evangelicals } \\
\text { disagree most }\end{array}$ & $\begin{array}{r}{ }^{* *} \text { Non-Es } \\
\text { agree more }\end{array}$ \\
\hline $\begin{array}{l}\text { Christians should } \\
\text { be willing to take } \\
\text { part in multi-faith } \\
\text { events where each } \\
\text { community offers } \\
\text { its own form of } \\
\text { scripture reading } \\
\text { prayer or worship. }\end{array}$ & $\begin{array}{r}* * \text { women } \\
\text { agree } \\
\text { more }\end{array}$ & NSD & NSD & $\begin{array}{r}\text { ** Presbyterians } \\
\text { and "other" } \\
\text { evangelicals } \\
\text { disagree most }\end{array}$ & $\begin{array}{r}* * \text { Non-Es } \\
\text { agree more } \\
\text { strongly }\end{array}$ \\
\hline $\begin{array}{l}\text { Christians should } \\
\text { oppose the building } \\
\text { of mosques or } \\
\text { temples in their } \\
\text { neighbourhood. }\end{array}$ & NSD & $\begin{array}{r}\text { ** older } \\
\text { people } \\
\text { agree most } \\
\text { younger } \\
\text { least }\end{array}$ & NSD & $\begin{array}{r}\text { ** Presbyterians } \\
\text { and "other" } \\
\text { evangelicals } \\
\text { agree most- } \\
\text { Free church least }\end{array}$ & $\begin{array}{r}\text { ** Non-Es } \\
\text { disagree more } \\
\text { strongly }\end{array}$ \\
\hline $\begin{array}{l}\text { Britain is an } \\
\text { essentially secular } \\
\text { country. }\end{array}$ & NSD & NSD & NSD & $\begin{array}{l}\text { * Presbyterians } \\
\text { and "other" } \\
\text { evangelicals } \\
\text { agree most- } \\
\text { Anglicans least }\end{array}$ & NSD \\
\hline $\begin{array}{l}\text { Britain is not so } \\
\text { much a secular } \\
\text { country as a } \\
\text { tolerant, religiously } \\
\text { plural one. }\end{array}$ & NSD & NSD & $\begin{array}{r}\text { ** Leaders } \\
\text { agree } \\
\text { more } \\
\text { - non } \\
\text { leaders } \\
\text { more } \\
\text { likely } \\
\text { to be } \\
\text { uncertain }\end{array}$ & $\begin{array}{r}\text { * Presbyterians } \\
\text { and "other" } \\
\text { evangelicals } \\
\text { disagree most- } \\
\text { Anglicans least }\end{array}$ & $\begin{array}{r}* \text { Non-Es agree } \\
\text { more }\end{array}$ \\
\hline
\end{tabular}




\begin{tabular}{|c|c|c|c|c|c|}
\hline $\begin{array}{l}\text { SIGNIFICANT DIF- } \\
\text { FERENCES BE- } \\
\text { TWEEN SUB- } \\
\text { GROUPS ON CHI } \\
\text { SQUARE TESTS. } \\
* * \text { P<.01* P< } \\
.05\end{array}$ & GENDER & AGE & LEADER & $\begin{array}{l}\text { DENOMINA- } \\
\text { TION }\end{array}$ & $\begin{array}{l}\text { COMPARED } \\
\text { WITH NON } \\
\text { EVANGELI- } \\
\text { CAL RESPON- } \\
\text { DENTS }\end{array}$ \\
\hline $\begin{array}{l}\text { Britain is essentially } \\
\text { a Christian country }\end{array}$ & $\begin{array}{r}* \text { women } \\
\text { agree } \\
\text { more }\end{array}$ & $\begin{array}{r}\text { ** older } \\
\text { people } \\
\text { agree most } \\
\text { younger } \\
\text { least }\end{array}$ & NSD & NSD & $\begin{array}{r}* \text { Non-Es agree } \\
\text { more }\end{array}$ \\
\hline
\end{tabular}

TABLE 6 Some significant differences between sub-groups.

\section{References}

Ahmed, Abdul-Azim. 2015. "A Short History of Interfaith in the UK." On Religion. http://www.onreligion.co.uk/interfaith-in-the-uk-ashort-historyl.

Atherstone, Andrew. 2018. "Evangelicals and Islam." In The Routledge Research Companion to the History of Evangelicalism, edited by Andrew Atherstone, and David Ceri Jones, 127-145. London: Routledge.

Baillie, Sandra. 2002. Evangelical Women in Belfast. London: Palgrave Macmillan.

Barber, Benjamin. 1992. "Jihad vs. McWorld." The Atlantic Monthly 269 (3): 53-65.

Barth, Fredrik. (1969) 1998. Ethnic groups and boundaries: The social organization of culture difference. Long Grove, II.: Waveland Press.

Bauder, Kevin, Albert Mohler Jr., John G. Stackhouse Jr., and Roger E. Olson. 2011. Four Views on the Spectrum of Evangelicalism. Zondervan. 
Bebbington, David W. 1989. Evangelicalism in Modern Britain: A History from the 1730s to the 1980s. London: Routledge.

Bebbington, David W. 2015. "The Evangelical Quadrilateral: A Response." Fides et Historia 47 (1): 87-96

Bell, Steve, and Colin Chapman. 2011. Between Naivety and Hostility: How Should Christians Respond to Islam in Britain? Authentic Media Inc.

Birt, Jonathan. 2006. "Good Imam, Bad Imam: Civic Religion and National Integration in Britain post-9/11." The Muslim World 96 (4): 687-705.

Cantle, Ted. 2001. Community Cohesion: A Report of the Independent Review Team. Home Office London.

Casey, Lousie. 2016. The Casey Review: A review into opportunity and integration. An independent review by Dame Louise Casey into opportunity and integration. Ministry of Housing, Communities $\&$ Local Government.

Cimino, Richard. 2005. “'No God in Common:' American Evangelical Discourse on Islam after 9/11." Review of Religious Research 47 (2): 162-174.

CNN. 2003. "Franklin Graham conducts services at Pentagon." CNN International, April 18. http://edition.cnn.com/2003/ ALLPOLITICS/04/18/graham.pentagon/.

ComRes / Evangelical Alliance. 2017. "Mapping Practising Christians." Talking Jesus. Accessed March 12, 2018. http://www.talkingjesus. org/research/mapping-practising-christians.

Cunningham, Lawrence. 2004. Francis of Assisi: Performing the Gospel of Life. Eerdmans Publishing. 
_-_. 2006. "St. Francis and Christian-Muslim Relations." ZENIT Daily Dispatch, EWTN, March 29. https://www.ewtn.com/library/ CHISTORY/francsmuslm.htm.

Evangelical Alliance. n.d. Basis of Faith. Accessed March 26, 2018. http:// www.eauk.org/connect/about-us/basis-of-faith.

_-_. 2011-2016. 21st Century Evangelicals Resources. Accessed March 26, 2018. https://www.eauk.org/church/resources/snapshot/ read.cfm.

Gidron, Noam, and Bart Bonikowski. 2013. “Varieties of Populism: Literature Review and Research Agenda." Weatherhead Center for International Affairs Working Paper Series 13 (4). https://wcfia.harvard.edu/files/wcfia/files/gidron_bonikowski populismlitreview_2013.pdf.

Gladwin, Michael. 2018. "Evangelicals and Mission in the Global South." In The Routledge Research Companion to the History of Evangelicalism, edited by Andrew Atherstone, and David Ceri Jones, 162-175. London: Routledge.

Goodstein, Laurie. 2003. "Seeing Islam as 'Evil' Faith, Evangelicals Seek Converts." New York Times 27: 1. https://www.nytimes. com/2003/05/27/us/seeing-islam-as-evil-faith-evangelicals-seekconverts.html.

Graham, Franklin. 2015. “Four innocent Marines.” Facebook, July 17, 2015. https://www.facebook.com/FranklinGraham/posts/96730535332 5646

Hartley, John. 2016. “Religious Exclusivists Taking Inclusive Action? Theorizing Exclusivist Practice in Muslim-Christian Relations.“ PhD diss., Yale University. 
Hewitt, Gordon. 1971. The Problems of Success: a History of the Church Missionary Society, 1910-1942. Volume 1: In tropical Africa, the Middle East, at home. SCM Press.

Hofstadter, Richard. 1964 "The Paranoid Style in American Politics." Harpers Magazine (Nov): 77-86.

Holmes, Stephen R. 2015. “Evangelical Theology and Identity." In 21st Century Evangelicals, edited by Greg Smith, 23-36. Watford: Instant Apostle.

Hughes, Dewi. 2016. The World on our Doorstep. London: Evangelical Alliance.

Huntington, Samuel P. 1993. “The Clash of Civilizations?" Foreign affairs (Summer): 22-49.

Kidd, Thomas S. 2009. American Christians and Islam: Evangelical Culture and Muslims from the Colonial Period to the Age of Terrorism. Princeton University Press.

Lewis, Bernard. 1994. Islam and the West. Oxford University Press.

- - - 2002. What went wrong? The Clash between Islam and Modernity in the Middle East. London: Weidenfeld \& Nicolson.

- - - 2004. The Crisis of Islam: Holy War and Unholy Terror. Random House Incorporated.

Marzouki, Nadia, Duncan McDonnell, and Oliver Roy, eds. 2016. Saving the People: How Populists Hijack Religion. Oxford University Press.

McCallum, Richard. 2011a. "A sociological Approach to Christian-Muslim Relations." PhD diss., University of Exeter.

_- - 2011b. "The Spectrum of Evangelical Responses to Islam in Britain." In Between Naivety and Hostility: How Should Christians Respond to Islam in Britain?, edited by Steve Bell, and Colin Chapman, 50-63. Authentic Media Inc. 
- - 2012. "Love: A Common Word between Evangelicals and Muslims?" Political Theology 13 (4): 400-413.

- - - 2016. "Rejection or Accommodation? Trends in evangelical Christian Responses to Muslims." In Religion and Knowledge: Sociological Perspectives, edited by Matthew Guest, and Elisabeth Arweck, 115-132. London: Routledge.

Murray, Ian H. 1971. The Puritan Hope: A study in Revival and the Interpretation of Prophecy. Banner of Truth Trust.

Neighborly Faith Website. 2018. Evangelicals for inter-religious engagement. http://neighborlyfaith.org/home/.

Neill, Stephen. 1964. A History of Christian Missions. London: Penguin. Pew Foundation. 2017. “U.S. Muslims Concerned About Their Place in Society, but Continue to Believe in the American Dream: Findings from Pew Research Center's 2017 survey of U.S. Muslims." Pew Research Center, July 26. http://www.pewforum. org/2017/07/26/findings-from-pew-research-centers-2017survey-of-us-muslims/.

Porter, Andrew N. 2000. "Evangelicalism, Islam, and Millennial Expectation in the Nineteenth Century." International Bulletin of Missionary Research 24 (3): 111-118.

-_-. 2004. Religion versus empire?: British Protestant missionaries and overseas expansion, 1700-1914. Manchester University Press.

Runnymede Trust. 2017. Islamophobia. Accessed March 26, 2018. https://www.runnymedetrust.org/projects-and-publications/ equality-and-integration/islamophobia.html.

Smith, Greg. 2002. "Religion and the Rise of Social Capitalism." Community Development Journal (April): 167-177. 
- - . 2004. "Faith in community and communities of faith? Government rhetoric and religious identity in urban Britain." Journal of Contemporary Religion 19 (2): 185-204.

---, ed. 2015. 21st Century Evangelicals, Reflections on Research by the Evangelical Alliance. Watford: Instant Apostle.

Smith, Gregory A., and Jessica Martínez. 2016. "How the faithful voted: A preliminary 2016 analysis." Pew Research Centre, November 9. http://www.pewresearch.org/fact-tank/2016/11/09/how-thefaithful-voted-a-preliminary-2016-analysis/.

Spector, Stephen. 2009. Evangelicals and Israel: The Story of American Christian Zionism. Oxford: Oxford University Press.

Strhan, Anna. 2014. "English evangelicals, equality and the city." In Globalized Religion and Sexual Identity: Contexts, Contestations, Voices, edited by Heather Shipley, 236-255. Leiden: Brill

---. 2015. Aliens and Strangers?: The Struggle for Coherence in the Everyday Lives of Evangelicals. Oxford University Press.

Taylor, Jenny. 2003. "After Secularism: British government and the Inner Cities." In Predicting Religion: Christian, Secular and Alternative Futures, edited by Grace Davie, Paul Heelas, and Linda Woodhead, 120-134. London: Ashgate.

Warner, Robert. 2007. Reinventing English Evangelicalism, 1966-2001: A Theological and Sociological Study. Wipf and Stock Publishers. Woodhead. Linda and Greg Smith. Forthcoming. "Religion and Brexit: Populism and the Church of England." Religion, State and Society (Special Issue on Populism).

YouGov. 2014. Survey of Anglican Clergy for Westminster Faith Debates. Accessed March 2, 2018. http://cdn.yougov.com/cumulus uploads/document/5f5s31fk47/Results-for-Anglican-ClergySurvey-08092014.pdf. 